\title{
The Effect of Corporate Governance Mechanisms on Firms' Financial Performance: Evidence from Selected Commercial Banks in Ethiopia
}

\author{
Megbaru Tesfaw Molla \\ College of Business and Economics, Department of Accounting and Finance, Debre Markos University, \\ P.O.Box 269, Debre Markos Ethiopia
}

\begin{abstract}
Corporate governance has become subject to the development agenda of most developed and developing countries economy, due to the fact that corporate governance structure of a firm has critical impact on its financial performance. Corporate governance mechanisms emerge to tackle agency problems in ensuring that shareholders' funds are not expropriated or wasted on unprofitable activities. The results of most research studies reveal that, well governed firms have been noted to have higher firm performance than poor governed firms. However, there are different researchers who opposed this idea as they have found mixed results on the relationships between different variables of corporate governance and financial performance. Research studies on this issue in developing countries; especially in Ethiopia remained an ignored area from empirical research. Thus, this study examined the effect of corporate governance mechanisms on firms' financial performance on the selected commercial banks in Ethiopia by taking a sample of 6 commercial banks starting from the year 2003 up to 2009. This study used return on asset, return on equity and operating profit margin as dependent variables to measure financial performance of commercial banks and board size, board independence, frequency of board meetings, chief executive officer duality, audit committee and board ownership as independent variables to express quantitatively corporate governance mechanisms. In addition, firm size, financial leverage and firm growth rate were used as control variables, which are specific to commercial banks and general to the economy as a whole. The researcher used both correlation analysis and pooled panel data regression models of cross-sectional and time series data for analysis. The results provide evidence that board size is negatively and significantly related with all the three indicators of financial performance- return on asset return on equity and operating profit margin. Audit committee and financial performance indicators-return on asset and return on equity is negative and statistically significant, but it is not significant with operating profit margin. Board independence, chief executive officer duality and board ownership are positively and significantly related with all the three financial performance indicators. However, frequency of board meetings is not statistically significant with all the three financial performance indicators.
\end{abstract}

Keywords: Corporate Governance Mechanisms, Agency Problem, Firms' Financial Performance and Commercial Banks.

DOI: $10.7176 /$ RJFA/10-21-05

Publication date: November $30^{\text {th }} 2019$

\subsection{Background of the Study}

According to the report of UNESCAP (2007), the definition of governance is defined as the process of decision making by which decisions are implemented or not implemented in corporate business firms. Berghe and Ridder (1999) acknowledged that corporate governance needs to put in place the structures and processes which make it possible for a business firm to pursue its strategy effectively to improve its financial performance.

In 1997, Shleifer and Vishny defined corporate governance mechanisms as follows: "Corporate governance mechanisms are ways to reduce the agency costs, where they attempts to minimize two types of agency conflicts: first, the conflicts between shareholders (owners) and managers; second, the conflicts between controlling majority shareholders and minority shareholders" (Shleifer \& Vishny, 1997, p. 737).

The need for corporate governance arises from the potential conflicts of interest between stakeholders such as chief executive officers, board members and shareholders within the business organizations. In their study of 2007, Imam and Malik (2007) acknowledged that potential conflict of interest between stakeholders within the business firms usually arises from the following two reasons. The first reason is different participants have different objectives and preferences. The second reason is the participants have imperfect information each other's actions, knowledge, and preferences. Therefore, corporate governance used to scale back agency issues in a very business firm to confirm that shareholders' investment isn't expropriated on unprofitable activities.

There are different theories on corporate governance and agency problem that this study incorporated to investigate the effect of corporate governance mechanisms on firms' financial performance. These are the agency theory, shareholders' theory and stakeholders' theory (Maria \& Thomas, 1999). According to Hsiang-tsui (2005), firms which apply best practice of corporate governance systems provide more useful information to 
investors and its other stakeholders to reduce agency problem as well as to help the company to improve its financial performance.

There are different mechanisms of corporate governance used to reduce agency cost, by which corporate governance is measured in a business firm. These are board size, board independence, frequency of board meetings, chief executive officer duality, audit committee, board ownership and so on. Those mechanisms are essential issue to the efficient use of investments invested by corporate business firms. Poor corporate governance is become critical issue in a corporate business firm as it has a critical negative impact on its financial performance (Klein et al. 2005).

There are several studies on the relationship between corporate governance and firm financial performance. From these studies most of them said that; Companies with better corporate governance have better financial performance than those companies with poor corporate governance (Jensen \& Meckling, 1976). However, Sunday (2008) found a mixed result on the relationship between corporate governance mechanisms and firm financial performance, which was revealed the following results: positive and significant relationship between return on equity and board size, return on equity and chief executive status, profitability margin and chief executive status, but there is no significant relationship between return on equity, board composition and audit committee and profitability margin and board size, board composition and audit committee. Another researcher, Ponnu (2008) examined a study on this area in Malaysian public listed companies and found that there no significant relationship between duality and board independence to firms' financial performance. Thus, the researcher is forced to conduct a study on the effect of corporate governance mechanisms on firms' financial performance by taking evidence from commercial banks in Ethiopia whether to check that corporate governance has a significant effect on the financial performance of firms.

\subsection{Statement of the Problem}

Shleifer and Vishny (1997) stated that both chief executives and shareholders should have one objective of maximizing firms' financial performance. However, the separation of shareholders from chief executives with the absence of corporate governance mechanisms provides executives with the ability to act in their own self interest that may not be in line with those of the shareholders; thus causes agency problem that eventually lead to poor financial performance. Therefore, corporate governance mechanisms affect the financial performance of a firm. There are different mechanisms by which corporate governance can be measured in an organization. Some of these variables are board size, board independence, frequency of board meetings, chief executive officer duality, and audit committee and board ownership.

The effect of corporate governance mechanisms on firms' financial performance have been substantially studied by different researchers, (Hiraki et al. 2001; Zunaidah \& Fauzias, 2010; Sanda et al. 2005). These and other researchers investigated their study on this area and identified both significant and insignificant relationship between corporate governance mechanisms and firms' financial performance by taking different variables that determine corporate governance and the financial performance of firms. However, almost all of these studies conducted on large firms operating within well organized corporate governance mechanisms in developed economic system. From such findings it is difficult to generalize the same result on the effect of corporate governance mechanisms on firms' financial performance for relatively small size commercial banks governance mechanisms in Ethiopia. As per the researchers knowledge research studies on the effect of corporate governance mechanisms on banking firms' financial performance in developing countries; especially in Ethiopia remained an ignored area of empirical research. Thus, with these serious shortcomings of the current literature, this study contributes to the existing literature by studying the issue with commercial banks in Ethiopia.

The banking industry plays a critical role in the efficient allocation of capital in an economy (Yung, 2009). It also promotes monetary and financial stability to the economy as a whole. Thus, this study is conducted by taking the commercial banking industry of Ethiopia as the study area to examine the effect of corporate governance mechanisms on firms' financial performance.

By considering the above situations, the researcher motivated to conduct this study by taking appropriate variables which can go with the conditions and situations of Ethiopian commercial banks governance mechanisms to come up with concrete results. Generally, this study is conducted with the aim of providing answers to the following basic research questions:

1. Do corporate governance mechanisms have a significant effect on banks' financial performance?

2. What are the possible determinant factors of corporate governance mechanisms that affect banks' financial performance?

3. In what way the dependent variables are related with independent variables?

\subsection{Objectives of the Study}

\subsubsection{General objective of the study}

The general objective of this study is to examine the effect of corporate governance mechanisms on firms' 
financial performance by taking evidence from selected commercial banks in Ethiopia, while controlling for a number of banking firms' specific factors that may affect commercial banks financial performance by using data from the year 2003 up to 2009.

\subsubsection{The specific objectives of the study}

The specific objectives of this study are:

1. To examine whether corporate governance mechanisms have a significant effect on banks' financial performance.

2. To identify the possible determinant factors of corporate governance mechanisms that affect banks' financial performance.

3. To analyze the way in which dependent variables are related with independent variables.

\subsection{Hypothesis of the study}

$\mathrm{H}_{06}$ : There is no significant relationship between board ownership and financial performance.

$\mathrm{H}_{05}$ : There is no significant relationship between the proportion independent audit committee and financial performance.

$\mathrm{H}_{04}$ : There is no significant relationship between chief executive officer duality and financial performance.

$\mathrm{H}_{03}$ : There is no significant relationship between the frequency of board meetings and financial performance.

$\mathrm{H}_{02}$ : There is no significant relationship between independent directors sitting on the board and financial performance.

$\mathrm{H}_{01}$ : There is no significant relationship between board size and financial Performance.

\subsection{Conceptual Framework}

Figure1: Conceptual framework for analysis

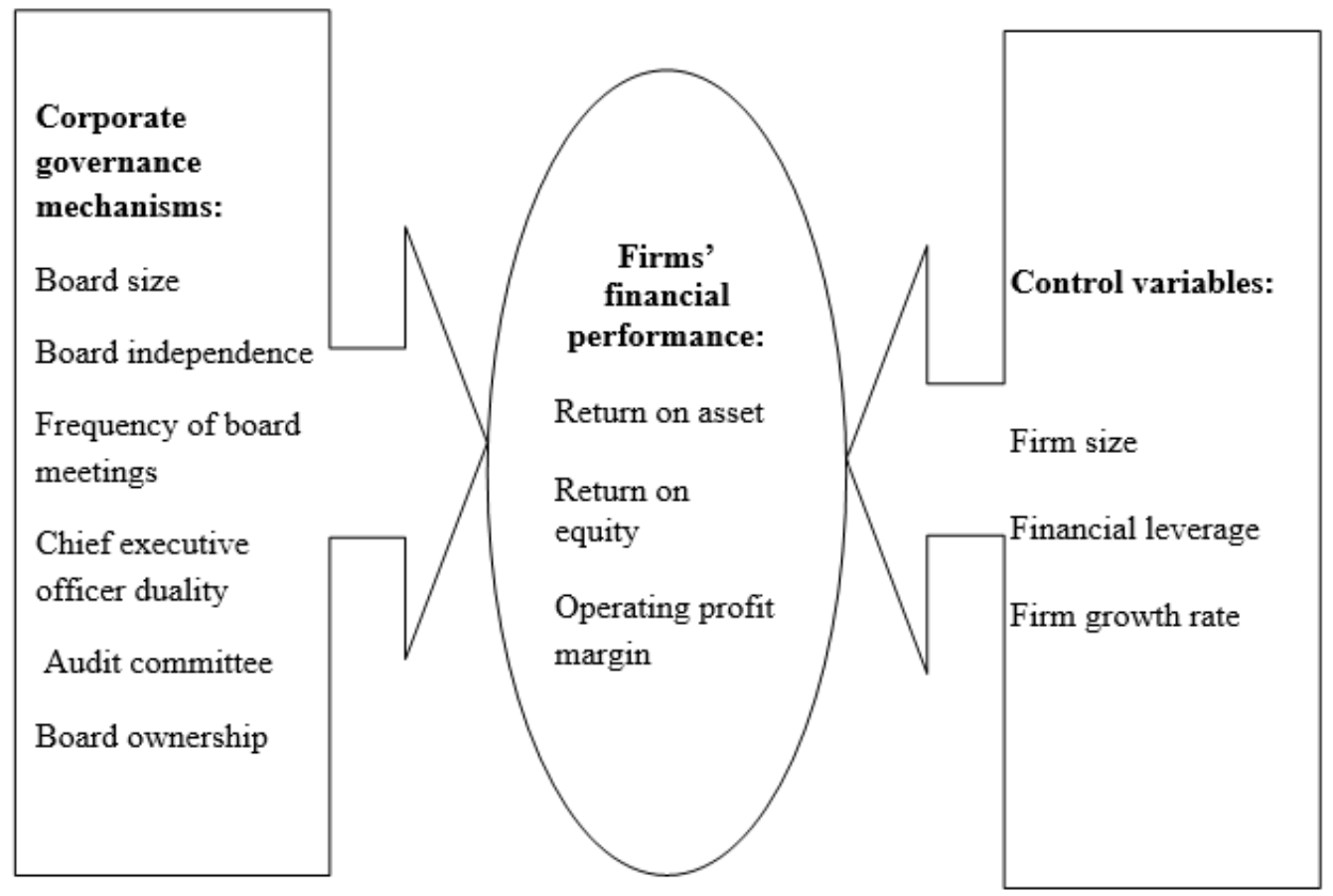

Source: Researcher's own design

\subsection{METHODOLOGY OF THE STUDY}

\section{Research Design}

This study has employed an explanatory survey research design following more of quantitative approach to examine the effect of corporate governance mechanisms on firms' financial performance on selected commercial banks in Ethiopia. Explanatory research design shows the relationship between two variables. The research design in this study used a pooled panel data analysis, which includes both a time series (inter-period) and cross sectional (inter-firm) data analysis. Pooled panel data analysis, also called the constant coefficients model, which has constant coefficients, referring to both intercepts and slopes are constant. It assumes that, there is no significant cross section or temporal effects, where the cross section firm data and time series data are pooled together in a single column and run OLS estimation (Yaffee, 2003). 


\section{Data Source and Collection Methods}

Data for this study were collected from both primary and secondary sources. Secondary data i.e. audited financial statements including balance sheet and income statement related to each bank were obtained from National Bank of Ethiopia for 7 year period i.e. 2003 up to 2009. Data required for this study found in National Bank of Ethiopia were limited in number of years, thus this study included only 6 commercial banks audited financial statements for 7 year. Financial statement data for 2002 was not available for this study that would have been used to compute the control variable, firm growth rate for the year 2003. The researcher found it is better to take the following 6 years average firm growth rate for the year 2003 rather than omitting it, by believing that it is better to increase the number of observations by not excluding all variables for the year 2003 because of one control variable. Primary data related to corporate governance mechanisms were obtained by using research questionnaires from the respective commercial banks' head offices of the chairman of boards in Addis Ababa. In addition to quantitative data qualitative data were also collected to support quantitative data by qualitative data.

\section{Sampling Design}

The total population of this study is all commercial banks in Ethiopia. In selecting banks included in this study, a purposive sampling design has been used. The sampling method used is also purposive sampling technique, where each sample elements are selected purposively so as to assure representation of the total population. Currently, 13 commercial banks are operating in Ethiopia. From the total commercial banks in Ethiopia 6 commercial banks are selected on the bases of age of commercial banks since incorporated and audited financial statement availability in National Bank of Ethiopia for the study period. The sampled commercial banks are Commercial Bank of Ethiopia, Dashen Bank, Awash International Bank, Bank of Abyssinia, United Bank and Nib International Bank.

\section{Data Analysis}

In this study descriptive statistics were used as the first stage of the analysis of data to provide detail information about each relevant variables used. At this stage, mean, standard deviation, maximum and minimum values of the required variables have been computed. In addition, to estimate the relationships between the dependant and independent variables and to test the hypothesis, the researcher has used two quantitative analysis methods. First, pair wise correlation analysis is used to measure the degree of association between the dependent variables and each explanatory variable. Second, multiple regression models of independently pooled panel regression are used to analyze the fundamental relationships of the dependant, independent and control variables. The method of estimation used was pooled OLS method. Therefore, by pooling the cross sectional data of 7 years for 6 commercial banks the pooled OLS estimation makes 42 observations.

Stata10.0 software was used for the purpose of analysis and to test model accuracy and other econometric problems like, normality and heteroskedasticity. The result of analysis was presented by using tables. Furthermore, qualitative data was also analyzed to support the results obtained from quantitative data.

\section{Model Specification}

In this study the following general econometric model (which is mostly found in most of the literatures of corporate governance mechanisms) was used to estimate quantitatively the effect of corporate governance mechanisms on firms' financial performance on selected commercial banks in Ethiopia.

Where:

$$
\mathrm{Yi}=\beta 0+\sum \beta \mathrm{iXi}+\varepsilon \mathrm{i}
$$

$>\mathrm{Yi}$ are the $\mathrm{i}^{\text {th }}$ observation of dependent variables (ROA, ROE and OPM)

$>\beta 0$ is the constant or intercept term

$>\quad \mathrm{Bi}$ are the coefficients of the $\mathrm{Xi}$ variables

$>\mathrm{Xi}$ are the $\mathrm{i}^{\text {th }}$ observation of the explanatory variables (BSIZE, BINDP,FBM, CEOD, AUDCM, BOWN,

FS, FL and FGR)

ei is the error term of the models

Specifically, when the above general model is changed into the specified variables of this study, the regression equations are as follows to estimate the effect of corporate governance mechanisms on firms' financial performance on selected commercial banks in Ethiopia:

$$
\begin{aligned}
& \mathrm{ROA}=\beta 0+\beta 1(\mathrm{BSIZE})+\beta 2(\mathrm{BINDP})+\beta 3(\mathrm{FBM})+\beta 4(\mathrm{CEOD})+\beta 5(\mathrm{AUDCM})+\beta 6(\mathrm{BOWN})+\beta 7(\mathrm{FS})+
\end{aligned}
$$

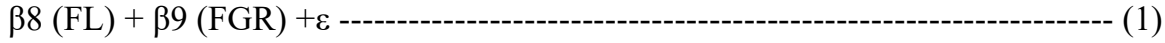

$$
\begin{aligned}
& \mathrm{ROE}=\beta 0+\beta 1(\mathrm{BSIZE})+\beta 2(\mathrm{BINDP})+\beta 3(\mathrm{FBM})+\beta 4(\mathrm{CEOD})+\beta 5(\mathrm{AUDCM})+\beta 6(\mathrm{BOWN})+\beta 7(\mathrm{FS})+
\end{aligned}
$$

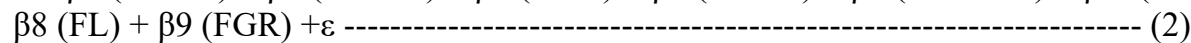

$$
\begin{aligned}
& \mathrm{OPM}=\beta 0+\beta 1(\mathrm{BSIZE})+\beta 2(\mathrm{BINDP})+\beta 3(\mathrm{FBM})+\beta 4(\mathrm{CEOD})+\beta 5(\mathrm{AUDCM})+\beta 6(\mathrm{BOWN})+\beta 7(\mathrm{FS})+ \\
& \beta 8(\mathrm{FL})+\beta 9(\mathrm{FGR})+\varepsilon-\left(\mathrm{c}-\mathrm{c}^{-}\right.
\end{aligned}
$$


$>$ BSIZE $=$ Board Size: Number of directors setting on the board

$>\mathrm{BINDP}=$ Board Independence: Number of independent directors sitting on the board (no significant connection with the bank)

$>\mathrm{FBM}=$ Frequency of board meetings: The number of board meetings held per year

$>\mathrm{CEOD}=$ Chief Executive Officer Duality: Value zero (0) if the same person occupies the chairman of the board and the chief executive and one (1) otherwise.

$>\mathrm{AUDCM}=$ Audit Committee: The composition of the audit committee, that is, independent as a proportion/ percentage of the total member for banks audit committee.

$>$ BOWN=Board Ownership: Number of board members, who has share contribution for the bank

$>$ FS=Firm Size: The natural logarithm of total assets of the bank

$>\mathrm{FL}=$ Financial Leverage: The total amount owed by the bank divided by its total capital

$>\mathrm{FGR}=$ Firm growth rate: Change in annual revenue of the bank

\subsection{RESULT AND DISCUSSION}

Econometrics Analysis:

Summary of regression analysis for the study variables

\begin{tabular}{|c|c|c|c|c|c|c|}
\hline \multirow[b]{2}{*}{ Variables } & \multicolumn{2}{|c|}{ ROA } & \multicolumn{2}{|c|}{ ROE } & \multicolumn{2}{|c|}{ OPM } \\
\hline & $\begin{array}{c}\text { Coef. } \\
\text { (Std.Err.) }\end{array}$ & $\begin{array}{c}\text { t-value } \\
\text { (p-value) }\end{array}$ & $\begin{array}{c}\text { Coef. } \\
\text { (Std.Err.) }\end{array}$ & $\begin{array}{c}\text { t-value } \\
\text { (p-value) }\end{array}$ & $\begin{array}{c}\text { Coef. } \\
\text { (Std.Err.) }\end{array}$ & $\begin{array}{l}\text { t-value } \\
\text { (p-value) }\end{array}$ \\
\hline BSIZE & $\begin{array}{l}-.0128797 \\
(.007196)\end{array}$ & $\begin{array}{l}-1.79^{*} \\
(0.083)\end{array}$ & $\begin{array}{l}-.1608668 \\
(.0817235)\end{array}$ & $\begin{array}{l}-1.97^{*} \\
(0.058)\end{array}$ & $\begin{array}{l}-.1801143 \\
(.0321685)\end{array}$ & $\begin{array}{c}-5.60 * * * \\
(0.000)\end{array}$ \\
\hline BINDP & $\begin{array}{c}.0155271 \\
(.0076179)\end{array}$ & $\begin{array}{c}2.04 * \\
(0.050)\end{array}$ & $\begin{array}{l}.1867218 \\
(.0865145)\end{array}$ & $\begin{array}{l}2.16 * * \\
(0.039)\end{array}$ & $\begin{array}{l}.1744151 \\
(.042886)\end{array}$ & $\begin{array}{c}4.07 * * * \\
(0.000)\end{array}$ \\
\hline FBM & $\begin{array}{c}.00002 \\
(.0001607)\end{array}$ & $0.12(0.902)$ & $\begin{array}{l}.0000622 \\
(.0018251)\end{array}$ & $0.03(0.973)$ & $\begin{array}{c}.0018887 \\
(.0022742)\end{array}$ & $\begin{array}{c}0.83 \\
(0.412)\end{array}$ \\
\hline CEOD & $\begin{array}{l}.0542838 \\
(.0256519)\end{array}$ & $\begin{array}{l}2.12 * * \\
(0.042)\end{array}$ & $\begin{array}{c}.8272399 \\
(.2913238)\end{array}$ & $\begin{array}{c}2.84 * * * \\
(0.008)\end{array}$ & $\begin{array}{l}.1918925 \\
(.2523984)\end{array}$ & $\begin{array}{l}0.76^{* *} \\
(0.045)\end{array}$ \\
\hline AUDCM & $\begin{array}{l}-.0133299 \\
(.0071026)\end{array}$ & $\begin{array}{l}-1.88^{*} \\
(0.070)\end{array}$ & $\begin{array}{l}-.2763031 \\
(.0806623)\end{array}$ & $\begin{array}{c}-3.43 * * * \\
(0.002)\end{array}$ & $\begin{array}{l}-.0531907 \\
(.0550794)\end{array}$ & $\begin{array}{c}-0.97 \\
(0.341)\end{array}$ \\
\hline BOWN & $\begin{array}{l}.0138291 \\
(.007223)\end{array}$ & $\begin{array}{c}1.91 * \\
(0.065) \\
\end{array}$ & $\begin{array}{l}.1441433 \\
(.0820305) \\
\end{array}$ & $\begin{array}{c}1.76^{*} \\
(0.088)\end{array}$ & $\begin{array}{l}.1838949 \\
(.0339705) \\
\end{array}$ & $\begin{array}{l}5.41 * * * \\
(0.000)\end{array}$ \\
\hline FS & $\begin{array}{l}.0317745 \\
(.0052529)\end{array}$ & $\begin{array}{l}6.05^{* * * *} \\
(0.000)\end{array}$ & $\begin{array}{l}.4492022 \\
(.0596557)\end{array}$ & $\begin{array}{l}7.53 * * * \\
(0.000)\end{array}$ & $\begin{array}{c}.3153711 \\
(.0679033)\end{array}$ & $\begin{array}{r}4.64 * * * \\
(0.000)\end{array}$ \\
\hline FL & $\begin{array}{l}-.0008156 \\
(.0003675)\end{array}$ & $\begin{array}{l}-2.22 * * \\
(0.034) \\
\end{array}$ & $\begin{array}{l}-.0021245 \\
(.0041733)\end{array}$ & $\begin{array}{c}-0.51 \\
(0.614) \\
\end{array}$ & $\begin{array}{l}-.0129246 \\
(.0038636)\end{array}$ & $\begin{array}{c}-3.35^{* * * *} \\
(0.002) \\
\end{array}$ \\
\hline FGR & $\begin{array}{c}.016726 \\
(.0061221) \\
\end{array}$ & $\begin{array}{l}2.73 * * \\
(0.010) \\
\end{array}$ & $\begin{array}{c}.2481785 \\
(.0695275) \\
\end{array}$ & $\begin{array}{c}3.57 * * * \\
(0.001)\end{array}$ & $\begin{array}{l}.136673 \\
(.05197) \\
\end{array}$ & $\begin{array}{l}2.63^{* *} \\
(0.013) \\
\end{array}$ \\
\hline Number of obs & \multicolumn{2}{|c|}{42} & \multicolumn{2}{|c|}{42} & \multicolumn{2}{|c|}{42} \\
\hline $\mathrm{F}(9,32)$ & \multicolumn{2}{|c|}{$13.90 * * *(\mathrm{P}=0.0000)$} & \multicolumn{2}{|c|}{$7.77 * * *(\mathrm{p}=0.0000)$} & \multicolumn{2}{|c|}{$10.56 * * *(p=0.0000)$} \\
\hline R-squared & \multicolumn{2}{|c|}{0.7963} & \multicolumn{2}{|c|}{0.6862} & \multicolumn{2}{|c|}{0.6034} \\
\hline Adj R-squared & \multicolumn{2}{|c|}{0.7390} & \multicolumn{2}{|c|}{0.5979} & \multicolumn{2}{|c|}{-} \\
\hline Root MSE & \multicolumn{2}{|c|}{.00667} & \multicolumn{2}{|c|}{.07577} & \multicolumn{2}{|c|}{.07806} \\
\hline \multicolumn{7}{|c|}{ *** Indicates statistically significant at 1 percent Level of significant } \\
\hline \multicolumn{7}{|c|}{ ** Indicates statistically significant at 5 percent Level of significant } \\
\hline \multicolumn{7}{|c|}{ * Indicates statistically significant at 10 percent Level of significant } \\
\hline
\end{tabular}

As it is summarized in above table above, the explanatory power of the variables used in the three models, from the R-squared values are equal to 79.63 percent, 68.62 percent and 60.34 percent for return on assets, return on equity and operating profit margin respectively. This implies that 79.63 percent of the changes in return on assets, 68.62 percent of the changes in return on equity and 60.34 percent of the changes in operating profit margin are successfully explained by the variables used in the three models of this study. However, the remaining 20.37 percent of the changes in return on assets, 31.68 percent of the changes in return on equity and 39.66 percent of the changes in operating profit margin are caused by other factors that are not included in the models of this study. These results indicate the overall goodness-of-fit of the models used in this study.

Moreover, the overall significance of the three models, when measured by their respective F- statistics of 13.90, 7.77 and 10.56 with P-values of 0.0000; indicates that these models are well fitted at 1 percent level of significance. Here one can infer from the results of R-squared and F-statistics that the implemented models of this research are well fitted that corporate governance mechanisms have a significant effect on banks' financial 
performance. Therefore, the following part of the analysis enables the researcher to identify the possible determinant factors of corporate governance mechanisms that affect banks' financial performance and to analyze the way (direction of relationship) in which dependent variables are related with independent variables.

Table 4.5, indicates that board size has a coefficient estimates of $-0.0128797,-0.1608668$ and -0.1801143 and it is statistically significant at 10 percent level of significance for both return on asset and return on equity and 1 percent level of significance for operating profit margin. The coefficients of board size imply that commercial banks' financial performance is negatively related with the increase the number of board members. In other words, the higher the number of board members of commercial banks, the lower their financial performance achievement is and vice versa.

A subjective question was also asked to qualitatively check as to whether respondents believe the number of board size is appropriate for this institution or not (Qn. No. 7). All responded 'yes' and they have justified it by it is set by the agreement, but not by low and believed to be appropriate to run the responsibility of the board. The best justification given is that, if the number of board members is large, it creates conflict of interest between the board members, which erodes the wealth of the bank. The outcome of the analysis of both quantitative and qualitative data indicates that there is a negative relationship between board size and financial performance of sampled commercial banks in Ethiopia.

Bearing in mind that the first null hypothesis was there is no relationship between board size and financial performance. Since the (P-values) of board size are statistically significance at 10 percent level of significance for both return on asset and return on equity and 1 percent level of significance for operating profit margin, the null hypothesis is rejected and the alternate hypothesis is accepted, which says there is a significant relationship between board size and financial performance. Therefore, the outcome of this variable is in line with the proposed alternate hypothesis. Thus, there is a significant negative relationship between board size and financial performance of commercial banks in Ethiopia. This outcome has the support of Yermack (1996), Adusei (2011) and Sanda et al. (2005).

The relationship between board independence and all the three financial performance measures is positive. Board independence explains the financial performance of selected commercial banks with a coefficient $0.0155271,0.1867218$ and 0.1744151 and it is statistically significant at 10 percent, 5 percent and 1 percent levels of significance for return on asset, return on equity and operating profit margin respectively. The implication of this result is that for the sampled commercial banks in Ethiopia, there is a positive relationship between their financial performances and the independent directors sitting on the board. This means that the higher the number of independent directors sitting on the board the higher the financial performance of sampled commercial banks in Ethiopia and vice versa.

Respondents were asked to reflect their view as to whether they feel independent board members have significant contribution on the bank's operation over the dependent board members (Qn. No. 8). Though there are inadequate justifications given by the respondents on the significant contribution of independent board members have over dependant board members. Most of them had positive responses. Because if the board is occupied by dependent directors the respondents answered by saying dependent board members are better and the vice versa is true if the bank's board is occupied by independent directors. Even though the justifications given by the respondents could not enable the researcher to be sure, the quantitative regression result indicates that there is a significant positive contribution of independent directors sitting on the board on the financial performance of the sampled commercial banks in Ethiopia.

The second null hypothesis was hypothesized that there is no significant relationship between independent directors sitting on the board and financial performance. Since the (P-values) of board independence are significant at 10 percent, 5 percent and 1 percent level of significant for return on asset, return on equity and operating profit margin respectively, the null hypothesis is rejected and the alternate hypothesis is accepted. Therefore, the outcome of this variable is in line with the proposed alternate hypothesis. Thus, there is a significant positive relationship between board independence and financial performance of commercial banks in Ethiopia. This outcome supports the outcomes found by Fleming (2005), Nahar (2001), Pearce and Zahra (1992), Abu-Tapanjeh (2006), Sulong and Nor (2010) and Adusei (2011).

The relationship between frequency of board meetings and the three financial performance measures is not statistically significant. The implication of this result is that for the sample commercial banks in Ethiopia, there is no relationship between the financial performances of sampled commercial banks in Ethiopia and the frequency of board meetings conducted by the board. This means that frequency of board meetings has no predicative capability in the presence of other independent variables. This result is not surprising as it is in line with the following two reasons.

First, the researcher has found from the qualitative questions (Qn. No. 11) that the insignificant result of frequency of board meetings is in line with what has been subjectively found. The respondents were asked as to whether they believe that the increased the frequency of board meetings has significant contribution on banks operation or not. Among other things, the justification given included that, meeting is necessary at infantry stage 
of banks activity, but most of the commercial banks are now in their maturity (high development) stage in their activity, thus no board meeting is as such required to follow up the banks.

The second reason is that, the row data indicates that the trend of frequency board meetings does not have any increasing and decreasing way. For example, in Commercial Bank of Ethiopia in 2003 there were 43 board meetings; while there were 9 board meetings in 2009, in Awash International Bank from 2003-2008 there were 29 board meetings, while there were 45 board meetings in 2009. It is the same in the entire sampled banks that no common increasing or decreasing trend. However, the financial performances of selected commercial banks were almost in an increasing trend. From this unrelated relationship of the financial performance of sampled commercial banks in Ethiopia and frequency of board meetings it is clear to understand that there is no negative or positive relationship between frequency of board meetings and their financial performance.

The third null hypothesis stated that there is no significant relationship between frequency of board meetings and financial performance. Since the (P-values) of frequency of board meetings are insignificant for all the three financial performance indicators, the null hypothesis is accepted. Therefore, the outcome of this variable is not in line with the proposed alternate hypothesis. Thus, there is no significant relationship between frequency of board meetings and financial performance of commercial banks in Ethiopia.

The result of the relationship between chief executive officer duality and return on asset, return on equity and operating profit margin is positive and statistically significant at 5 percent, 1 percent and 5 percent significance levels respectively. It explains return on asset by 0.0542838 , return on equity 0.8272399 and operating profit margin by 0.1918925 . These results indicate that there is a positive relationship between chief executive officer duality and financial performance of selected commercial banks in Ethiopia. The inference of this result is that chief executive officer duality is not a problem in the context of Ethiopian commercial banks; rather the duality of chief executives of banks increases their financial performance.

In the qualitative part (Qn. No. 9), the respondents have replied that, in the current time the duality of chief executive officer is prohibited by the National Bank of Ethiopia. The respondents have said that, the situation of duality, which existed before, had both disadvantages and advantages for the bank. As the respondents have said, the main disadvantage of duality of executive officers is conflict of interest, while the main advantage is the decisions become more valuable when the executives participate in the process of implementing the guidelines and business strategies and also in the process of approval of activities to be implemented. From this qualitative analysis it is impossible to decide that duality of chief executive officer is better than non duality because it has both advantages and disadvantages. However, it is enough to say that duality has a positive contribution (advantage) for banks financial performance, because the advantage is supported by the quantitative analysis. Therefore, results of both quantitative and qualitative data analysis imply that there is a positive relationship between chief executive officer duality and financial performance of sampled commercial banks in Ethiopia.

The fourth null hypothesis stated that there is no significant relationship between chief executive officer duality and financial performance. Since the (P-values) of chief executive officer duality are significant at 5 percent, 1 percent and 5 percent level of significance for return on asset, return on equity and operating profit margin respectively, the null hypothesis is rejected and the alternate hypothesis is accepted. Therefore, the outcome of this variable is in line with the proposed alternate hypothesis. Thus, there is a significant positive relationship between chief executive officer duality and financial performance of commercial banks in Ethiopia. This outcome is supported by Sunday (2008), Sulong and Nor (2010), Sanda et al. (2005) and Boyd (1995).

Audit committee has a negative relationship with return on asset and return on equity. It is statistically significant at 10 percent and 1 percent significance levels with return on asset and return on equity respectively. But, it is not significant with operating profit margin. Audit committee explains both return on asset and return on equity by -0.0133299 and -0.2763031 respectively. These results indicate that there is a negative relationship between audit committee and return on asset and return on equity. The implication of this result is that the higher the proportion of independent audit committee the lower the return on asset and return on equity and vice versa.

The following question (i.e. Qn. No.10) was asked in relation role of independent audit committee. "What is the role of independent audit committee in your organization over the dependant audit committee?" Most of the respondents have justified that the role of independent audit committee is not greater than the role of dependent audit committee because dependent audit committees are more responsible than independent audit committee. This qualitative justification implies that the role of dependent audit committee is more than the role of independent audit committee in the operation of the banks. The quantitative analysis which indicates the higher the proportion of independent audit committee the lower the financial performance of sampled commercial banks in Ethiopia is supported by the qualitative analysis which acknowledges that the role of independent audit committee is not more than the role of dependent audit committee.

The fifth null hypothesis, hypothesis five says that there is no significant relationship between the proportion of independent audit committee and financial performance. Since the (P-values) of audit committee are significant at 10 percent and 1 percent for return on asset and return on equity, the null hypothesis is rejected and the alternate hypothesis is accepted in case when the financial performance of selected commercial banks 
measured by return on asset and return on equity. Therefore, the outcome of this variable is in line with the proposed alternate hypothesis, when financial performance is measured by return on asset and return on equity. Thus, there is a significant negative relationship between the proportion of outside audit committee and financial performance of sampled commercial banks in Ethiopia, when financial performance is measured by return on asset and return on equity. This result is in line with Klein (2002). However, when financial performance is measured by operating profit margin the (P-value) is insignificant, thus the null hypothesis is accepted, which says there is no significant relationship between the proportion of independent audit committee and financial performance. Therefore, the outcome of this variable is not in line with the proposed alternate hypothesis, when financial performance is measured by operating profit margin. This insignificant result of audit committee is in line with the result of Sunday (2008) and Aljifri and Moustafa (2007).

The effect of board ownership is positive and statistically significant with all the three financial performance indicators at 10 percent significance levels with return on asset and return on equity and 1 percent significant level with operating profit margin. Board ownership explains return on asset, return on equity and operating profit margin by $0.0138291,0.1441433$ and 0.1838949 respectively. These results indicate that there is a positive relationship between board ownership and financial performance of selected commercial banks in Ethiopia. This means that the higher the number of board members, who have share contribution for the bank, the higher the financial performance of sampled commercial banks in Ethiopia and vice versa.

This quantitative outcome is supported by qualitative question (Qn. No.12), which asks if there is any board member who has shares in the bank. Except for the Commercial Bank of Ethiopia, which is government owned; this was the case in all privately owned commercial banks in Ethiopia. In addition to this, the advantage of banks from these board members was asked. Respondents have replied that, the board members, who have share contribution have a great contribution for the bank's financial performance and development of the bank by using their full capacity, because it is their business. Thus, both the quantitative and qualitative data on board ownership indicates that when the number of board members, who have share contribution for the sampled commercial banks in Ethiopia, increases their financial performance also increases and vice versa.

The last null hypothesis states that there is no significant relationship between board ownership and financial performance. Since the (P-values) of board ownership are significant at 10 percent significance level with return on asset and return on equity and 1 percent significance for operating profit margin, the null hypothesis is rejected and the alternate hypothesis is accepted. Therefore, the outcome of this variable is in line with the proposed alternate hypothesis. Thus, there is a significant positive relationship between board ownership and financial performance of commercial banks in Ethiopia. This outcome is supported by the findings of Sulong and Nor (2010), Rose (2005) and Jensen and Meckling, (1976).

In addition to what has been discussed above, table 4.5 presents the result of the regression analysis between control variables and financial performance indicators of selected commercial banks in Ethiopia, which are interpreted as follows:

The first control variable, firm size has surprising result. It is statistically significant at 1 percent level and it explains return on asset, return on equity and operating profit margin at $0.0317745,0.4492022$ and 0.3153711 respectively. Firm size (measured in terms of the natural legalism of total asset) positively affects the financial performance of commercial banks in Ethiopia i.e. when firm size increases the financial performance of commercial banks in Ethiopia also increases.

The other control variable, financial leverage (the total amount owed by the firm divided by its total capital) explains both return on asset and operating profit margin by -0.0008156 and -0.0129246 respectively and statistically significant with only return on asset and operating profit margin at 5 percent and 1 percent significance levels while it is insignificant with the return on equity. The result implies that firm growth rate negatively affects financial performance of commercial banks in Ethiopia, when financial performance measured by return on asset and operating profit margin.

The last control variable, firm growth rate is positively and significantly related with the three regression models. It is statistically significant with return on asset, return on equity and operating profit margin at 5 percent, 1 percent and 5 percent significance levels respectively. Firm growth rate explains return on asset, return on equity and operating profit margin by $0.136673,0.2481785$ and 0.016726 respectively. These results imply that when the growth rate of commercial banks in Ethiopia increases their financial performance also increases and vice versa.

In general, in this study both correlation coefficient results of all the independent and control variables do not have the same sign for all the three financial performance indicators and in the regression results the significant and the way of relationship of all independent and control variables do not have the same result for all the three financial performance indicators. This is because financial performances indicators are not equally indicate the financial performance of banks, because financial performance indicators used different formulas with their limitations to indicate the ability of corporate governance mechanisms. For example return on asset indicates the overall efficiency of management and reflects whether the bank uses assets and liabilities 
effectively in order to produce its income. Return on equity provides information as to how well managers are using the funds invested by the shareholders without considering the effect of liability of the firm. Operating profit margin shows earning arising directly from the commercial operations of the firm without the effect of financing ability of the bank.

\subsection{Conclusions}

The purpose of this study is to investigates the effect of corporate governance mechanisms on firms' financial performance on selected commercial banks in Ethiopia using three financial performance indicators (return on asset, return on equity and operating profit margin) as dependent variables and six corporate governance mechanisms (board size, board independence, frequency of board meetings, chief executive duality, audit committee and board ownership) as independent variables. In addition, three control variables (firm size, financial leverage and firm growth rate) were used. A sample of 6 commercial banks were selected out of 13 commercial banks in Ethiopia and data covering the years 2003 to 2009 were used in this study. Panel data methodology was employed; the method of analysis was multiple regression and the method of estimation was pooled OLS. This study revealed the following results:

The regression result indicates that except frequency of board meetings and audit committee (in the case of relationship with operating profit margin) all the other corporate governance mechanisms have a significant effect on financial performance of selected commercial banks in Ethiopia. The researcher made the following conclusions on the possible determinant factors of corporate governance mechanisms that affect banks' financial performance and on the ways in which dependent variables are related with independent variables.

Board size is negatively and significantly related to all the three indicators of financial performance- return on asset return on equity and operating profit margin. These results are consistent with most of previous studies. The implication of this result is that the higher the number of board size, the lower the financial performance of commercial banks in Ethiopia. In other words, the increase in the number of board members in a bank could result in conflict of interest in decision making. The presence of conflict of interest leads to the decrease in the financial performance. Moreover, the higher number of board members may also contribute towards delayed decisions. Thus, the researcher concludes that board size negatively affects the financial performance of commercial banks in Ethiopia.

Board independence and all the three indicators of financial performance- return on asset, return on equity and operating profit margin are positively and significantly related. These results are supported by previous studies. The implication is there is a positive relationship between financial performances and the proportion of independent directors sitting on the board. This may be due to the reason that independent directors can stimulate in helping as a link by communicating with the outside environment, providing important and useful information. This enhances proper decision making of the banks activity. Therefore, the researcher concludes that board independence positively affects the financial performance of Ethiopian commercial banks.

Even thought the coefficients of frequency of board meetings are positive for all the three indicators of financial performance; it is not statistically significant with all the three financial performance indicators. The inference which could be made from this result is that, there is no relationship between the financial performances and the frequency of board meetings conducted. Hence, the researcher concludes that frequency of board meetings does not affect the financial performance of commercial banks in Ethiopia.

The relationship between chief executive officer duality and return on asset, return on equity and operating profit margin is positive and statistically significant. This result implies that there is a positive relationship between chief executive officer duality and financial performance of commercial banks in Ethiopia. This result is in line with previous studies, which argued that chief executive officer duality has a positive effect on commercial banks financial performance in Ethiopia. This outcome may be due to the fact that the decisions become more valuable when the executive officers participate in the process of implementing the guidelines and business strategies and also in the process of approval of activities to be implemented. By using this result, the researcher concludes that chief executive officer duality positively affects the financial performance of commercial banks in Ethiopia.

Audit committee has a negative relationship and statistically significant with return on asset and return on equity. But, it is not significant with operating profit margin. This result indicates that there is a significant negative relationship between the proportion of independent audit committee and financial performance of commercial banks in Ethiopia, when financial performance is measured by return on asset and return on equity. But, the proportion of independent audit committee does not affect financial performance of commercial banks in Ethiopia, when financial performance is measured by operating profit margin. Accordingly, the researcher concludes that audit committee has a negative significant effect on the financial performance of commercial banks in Ethiopia, when financial performance is measured by return on asset and return on equity, but it does not affect the financial performance of commercial banks in Ethiopia, when financial performance is measured by operating profit margin. 
Board ownership is positively and statistically significant with all the three financial performance indicators. These results are consistent with most of previous studies. This result implies that when the number of board members, who have share contribution for commercial banks increases, their financial performance also increases and the vice versa. This result may be because if the board member has a share contribution for the banks, $\mathrm{s} /$ he is more responsible for financial performance; because $\mathrm{s} / \mathrm{he}$ is the one to be the beneficial if the bank is stronger in its financial performance. Thus, the researcher concludes that board ownership positively affects the financial performance of commercial banks in Ethiopia.

\subsection{Recommendations}

This study attempts to investigate the effect of corporate governance mechanisms on firms' financial performance by taking evidence from selected commercial banks in Ethiopia. On the basis of the findings and conclusions reached in this study, the following recommendations were forwarded.

Even though commercial banks in Ethiopia apply corporate governance mechanisms, further considerations should be given to improve their financial performance. Specifically the researcher recommends commercial banks of Ethiopia as follows:

Attention should be given for the board size of banks to be small in number and for the composition of the board to be proportional by include both board members, who are independent for the commercial banks and board members, who have share contribution for commercial banks to improve their financial performance. This is because the finding of this study revealed that both the members of the board are positively related with the financial performance of commercial banks.

The finding of this study revealed that chief executive officer duality is not a problem in the context of Ethiopian commercial banks when it comes to their financial performance. With caution, it would be good then for commercial banks to encourage chief executive officer duality but continuously monitor its effect.

Attention should also be given for the proportion of audit committee. The commercial banks of Ethiopia should increase the number of dependent audit committees for the improvement of their financial performance. Because the result of this study indicates that the higher the number of independent audit committee as a proportion/ percentage of the total member of audit committee is negatively related with the financial performance of commercial banks, thus the number of independent audit committee should be dominated by dependent audit committee.

Regarding further research directions, this research highlights a number of issues that give directions on the effects of corporate governance mechanisms on firms' financial performance. Thus, by taking the previous studies and this study as a stepping stone, it could be possible to come up with a better insight. The outcome of this study can be more robust, if future researchers conduct a study on this area by: first, further increasing the study population and the sample size to the whole financial sector; second, taking evidence from manufacturing business firms or merchandising business firms as a study area; and third, increasing the number of observations based on the use of long time series data and sample size of the study.

\subsection{REFERENCES}

Abu-Tapanjeh, A. (2006). Good corporate governance mechanism and firms' operating and financial performance. Insight from the perspective of Jordan industrial companies. Journal of King Saud University, 19, (2), 101-121.

Adusei, M. (2011). Board structure and bank performance in Ghana. Journal of Money,Investment \& Banking, 19, ISSN 1450-288.

Aljifri, K. \& Moustafa, M. (2007). The impact of corporate governance mechanisms on the performance of United Arab Emirate (UAE) Firms: An Empirical Analysis. Journal of Economic \& Administrative Sciences, 23, (2), 71-93.

AL-Shubiri, F. (2010). Analysis the determinants of corporate philanthropy: A case study in the Jordanian Commercial Banks. Journal of Social Sciences, 6,(2), 244-251.

Al- Haddad,Y.M., Alzurqan,T.S. \& Al-Sufy, J.F. (2011). The effect of corporate governance on the performance of Jordanian industrial companies: An empirical study on Amman Stock Exchange. International Journal of Humanities \& Social Science, 1, (4), 55-69.

Amir, R. (2009). Corporate governance and financial performance: A study of Malaysian listed companies. University Malaya, 1-107.

Babatunde, M. \& Olaniran, O. (2009). The effect of internal and external mechanisms on corporate governance and performance of corporate firms in Nigeria. Corporate ownership and control, 7(2), 330-343.

Berghe, D. \& Ridder D. (1999). International standardization of good corporate governance. New York: Kluwer Academic Publisher. Retrieved from http://org.sagepub.com (Accessed on March 4, 2011).

Berle, A. \& Means, G. (1967). The modern corporation and private property: Revised edition, Harcourt Brace and World Inc, New York. Retrieved from http://wikipediaa.org. (Accessed on March 10, 2011). 
Bollaert,H., Hicham Daher, H., Aurélie Deroo,A. \& Dupire-Declerck, M.(2010). Corporate governance and performance of French listed companies. IESEG School of Management, LEM-CNRS (UMR 8179).

Boyd, B. (1995). CEO duality and firm performance: A contingency model. Journal Strategic Management, 16, 301-312.

Callaghan, M. (2005). The relationship between chief executive officer duality and subsequent corporate financial performance: Ph.D Dissertation, School of Business, Capella University. Retrieved from http://www.drjohnlatham.com. (Accessed on March 16, 2011).

Carcello, J. \& Neal, T. (2000). Audit committee composition and auditor reporting. The Accounting Review, 75, 453-467.

Charles, A. (1993). Corporate governance guidelines on best practices. Securities and exchange commission Ghana. Retrieved from http://www.secghana.org. (Accessed on February 12, 2010).

Cohen, J., Krishnamoorthy, G. \& Wright, A. (2004). The corporate governance mechanisms and financial reporting quality. Journal of accounting literature, 23, 87-152.

Fama, E. (1980). Agency problems and the theory of the firm. Journal of Political Economy, 88(2),288-307.

Fama, E. \& Jensen, M. (1983). Separation of ownership and control. Journal of Law \& Economics, 26(2), 301325.

Fleming, D. (2005). Principles of good corporate governance, code of good practice for boards and directors: Institute of Directors-Administrators, Madrid, Spain, $2^{\text {nd }}$ edition, 8-20.

Fosberg, R. (1989). Outside directors and managerial monitoring. Akron Business \& Economics Review,20,24-32. Gujirati, D.N. (2004). Basic econometrics, 4th edition, McGraw-Hill Higher Education.

Hiraki,T., Inoue, H., Ito, A., Kuroki,F. \& Masuda,H. (2001). Corporate Governance and Firm Value in Japan: Evidence from 1985 to 1998. Akitoshi Ito International University of Japan Yamato-machi, Niigata-ken, Japan, 949-7277.

Hsiang-tsui, C. (2005). An empirical study of corporate governance and corporate performance. Journal of American Academy of Business Cambridge, International Review of Business Research Papers, 4 (2), $217-$ 230.

Hunger, D. \& Wheelan, T. (1999). Strategic management, Addison-Wesley, Reading, Massachusetts.

Imam, M. \& Malik, M. (2007). Firm performance and corporate governance through ownership structure. Evidence from Bangladesh Stock Market. International Review of Business Research Papers, 3 (4), 88-110.

Jensen, M. \& Meckling, W. (1976). Theory of the firm: Managerial behavior, agency costs and ownership structure. Journal of Financial Economics, 3, 305-360.

Kim, D. \& Rasiah, D. (2010). Relationship between corporate governance and corporate performance in Malaysia during the pre and post Asian financial crisis. European Journal of Economics, Finance \& Administrative Sciences Issue, 21, 40-63.

Klein, A. (2002). Audit committee, board of director characteristics and earnings management. Journal of Accounting \& Economics, 33, 375- 400

Klein, P., Shapiro, D.M. \& Young, J. (2005). Rational for good corporate governance. Proving Adam Smith Wrong, 1-2.

Larcker, D. F., Richardson, S. A. \& Tuna, I. (2005). How important is corporate governance? Working paper University of Pennsylvania.

Lex, D. \& James, H. (1991). Stewardship theory or agency theory: CEO governance and shareholders returns. Australian Journal of Management, 16, 49-65.

Maria, M. \& Thomas, A. (1999). Corporate governance: effects on firm performance and economic growth, 6-10.

Nahar, A. (2001). Characteristics of board of directors and audit committees among Malaysian listed companies in the period leading to 1997 financial crises of Malaysia. Akauntan Nasional, 18-21.

OECD, (2004). Improving corporate governance standards: the work of the OECD and the principles: glob white page, Paris France. Retrieved from: www.oced .org. (Accessed on March 5, 2011).

Park, M. (2008). Univariate analysis and normality test using SAS, Stata and SPSS. Working Paper. The University Information Technology Services center for statistics and mathematics computing. http://www.indiana.edu/ statmath/stat/all/normality/index.html.

Pearce, J. \& Zahra, S. (1992). Board Composition: from contingency perspective. Journal of management studies, 29,411-438.

Ponnu, C. (2008). Corporate governance structures and the performance of Malaysian public listed companies. International Review of Business Research Papers, 4(2), 217-230.

Ramsey, J. (1969). Tests for specification errors in classical linear least squares regression analysis, Journal of the Royal Statistical Society. Series B (Methodological), 31(2), 350- 371.

Rechner, P. \& Dalton, D. (1991). CEO duality an organizational performance: A longitudinal analysis. Strategic Management Journal, 12,(2).

Robert, M. (2006). Agency Assurance: The role of the audit committee in corporate governance. St.Gallen: 
University of St. Gallen Press.

Rose, C. (2005). Managerial ownership and firm performance listed Danish firms. European Journal of Management, 23(5), 542-553.

Sanda, A.U, Mikailu, A.S. \& Garba, T. (2005). Corporate governance mechanisms and firms financial performance in Nigeria: The African Economic Research Consortium Research Paper, 149, Kenya regional press.

Shleifer, A. \& Vishny, R. (1997). A survey of corporate governance. Journal of Finance,52(2), 737-782

Sulong, Z. \& Nor, F. (2010). Analysis the determinants of corporate philanthropy: A case study in the Jordanian Commercial Banks. Journal of social science, 6, (2).224-251.

Sunday, O. (2008). Corporate Governance and Firm Performance: The Case of Nigerian Listed firms European. Journal of Economics, Finance \& Administrative science, 14.

Tandelilin,E., Kaaro, H. \& Mahadwartha,A.,P.(2007). Corporate governance, risk management, and Bank performance: Does type of ownership matter? Eadn working paper, 34. Retrieved from www.eadn.org. (Accessed on February 12, 2011).

UNESCAP (2007). What is good governance? Poverty and development division. Retrieved from: www.unescap.org (Accessed on February 26, 2011).

Xiaojun, B. \& Zhenhong, S. (2005). Corporate governance for One-man Company in view of the theory of stakeholders: School of Economics and Management, Shenyang Ligong University, P.R.China.

Yaffee, R. (2003). A primer for panel data analysis; produced by New York university information technology service. Retrieved from http://www.nyu.edu/pubs. (Accessed on April 09, 2011).

Yermack, D. (1996). Higher market valuation of companies with a small board of directors. Journal of Financial Economics, 40, 185-211.

Yung, C. (2009). The relationship between corporate governance and bank performance in Hong Kong. Auckland University of technology. Retrieved from http://www. Aut. researchgateway. (Accessed on April 09, 2011).

Zabihollah, R. (2003).Improving corporate governance: the role of audit committee disclosure. Journal of Managerial Auditing, 18(6/7), 530-537.

Zunaidah, S. \& Fauzias, M. (2010). Corporate governance mechanisms and firms valuation in Malaysian listed firms: A panel data analysis. Journal of Modern Accounting \&Auditing, 6, (1)/ (6), 1-18 